Volume 3, Nomor 1 Juni 2021

\title{
STRATEGI BELAJAR KOGNITIF UNTUK PEMBELAJARAN BAHASA ARAB
}

\author{
M. Kholis Amrullah1 \\ 1)IAIN Metro Lampung \\ 1)kholisamrullah@metrouniv.ac.id
}

\begin{abstract}
Abstrak. Proses belajar yang dilakukan peserta didik sebaiknya memiliki strategi belajar. Peserta didik yang aktif dalam belajar memiliki strategi belajar yang dapat menambah minat belajar yang baru dan memperbaiki proses belajar terhadap pembelajaran. Strategi kognitif terbagi menjadi tiga jenis yaitu: strategi mengulang, strategi organisasi dan strategi elaborasi. Penelitian ini bertujuan untuk mengetahui bagaimanakah strategi kognitif dalam pembelajaran bahasa Arab. Strategi pembelajaran dosen cenderung selalu mendapat perhatian sehingga kerap kali strategi belajar mahaanak didik diabaikan. Sedangkan strategi belajar mahaanak didik termasuk unsur penting dalam berhasilnya suatu pembelajaran. Strategi belajar mahaanak didik merupakan salah satu faktor dari dalam diri mahaanak didik berupa kemampuan strategis dalam cara belajar. Studi ini bertujuan untuk mendeskripsikan strategi belajar bahasa Arab berbagai faktor pendukung dan penghambatnya. Dengan pendekatan metode kualitatif deskriptif menunjukan bahwa strategi yang dominan digunakan dalam belajar bahasa Arab adalah strategi kognitif.
\end{abstract}

Kata kunci: Proses Belajar, Strategi Kognitif, Bahasa Arab

\begin{abstract}
The learning process carried out by students should have a learning strategy. Students who are active in learning have learning strategies that can add new interest in learning and improve the learning process towards learning. Cognitive strategies are divided into three types, namely: repetition strategies, organizational strategies and elaboration strategies. This study aims to determine how the cognitive strategies in learning Arabic. Lecturer learning strategies tend to always get attention so that students' learning strategies are often ignored. While the student learning strategy is an important element in the success of a learning. Student learning strategies are one of the factors from within students in the form of strategic abilities in how to learn. This study aims to describe Arabic learning strategies with various supporting and inhibiting factors. The descriptive qualitative method approach shows that the dominant strategy used in learning Arabic is cognitive strategy.
\end{abstract}

Keywords: Learning Process, Cognitive Strategy, Arabic

\section{PENDAHULUAN}

Tujuan pengajaran yang dilaksanakan di dalam kelas menurut Mager adalah menitik beratkan pada perilaku anak didik atau perbuatan (performance) sebagai suatu jenis output yang terdapat pada anak didik dan teramati serta menunjukan bahwa anak didik tersebut telah melaksanakan kegiatan belajar mengajar. 


\section{muhadasah \\ Jurnal Pendidikan Bahasa Arab \\ INSTITUT AGAMA ISLAM SUNAN KALIJOGO MALANG \\ P-ISSN 2622-6723 E-ISSN 2721-9488 \\ Volume 3, Nomor 1 Juni 2021}

Pengajar mengemban tugas utamanya adalah mendidik dan membimbing anak didik- untuk belajar serta mengembangkan dirinya. Di dalam tugasnya seorang pengajar diharapkan dapat membantu anak didik dalam memberi pengalaman-pengalaman lain untuk membentuk kehidupan sebagai individu yang dapat hidup mandiri di tengah-tengah masyarakat modern.

Tugas pengajar tidaklah berakhir tatkala telah selesai menyampaikan materi pelajaran di kelas dengan baik. Seorang pengajar juga bertanggung jawab untuk membina anak didik dalam memecahkan permasalahan yang dihadapinya sehari-hari, sehingga mereka betul-betul mampu mandiri dengan menggunakan fakta, konsep, prinsip dan teori-teori yang telah mereka peroleh di dalam kelas, demikian juga mereka dapat memecahkan masalah yang diberikan pengajar

Sering kita menemui anak didik mampu memecahkan masalah yang diberikan pengajar, kemudian setelah mereka menemui masalah di luar kelas atau di tengah-tengah masyarakat, mereka tidak mampu mengatasi masalah (yang hampir sama) yang dihadapinya, maka timbul pertanyaan dibenak kita, kenapa hal ini sampai terjadi!, barangkali suatu jawaban, masalah yang diberikan pengajar mudah dipecahkan atau masalah tersebut tidak menantang, mungkin juga masalah itu dipecahkan berkat bantuan pengajar atau teman-temannya, barangkali juga anak didik belum mampu mengaplikasikan ilmu, pengetahuan dan keterampilan yang mereka peroleh dari pengajarnya. Sebenarnya proses belajar di tingkat sekolah lanjutan mereka sudah dibekali dengan pengetahuan tingkat menengah (aplikasi, analisis) dalam kehidupannya dari apa yang mereka peroleh dari pengajar. Penilaian takosonomi B.S. Bloom tentang ranah kognitif terbagi dalam tiga kelompok, kelompok pengetahuan rendah, menengah dan tinggi. Aplikasi pada tingkat sekolah lanjutan sudah dimulai penggemblengan secara matang pada masing-masing tingkat yang mana anak didik telah memiliki kemampuan pengetahuan dan merupakan tujuan tersebut, begitu juga mampu menstransfer pengetahuan ke dalam dirinya dan merupakan transfer of knowledge, maka hal demikian dapat disebut strategi kognitif. ${ }^{1}$

Kemampuan kognitif manusia dapat menghadirkan realitas dunia ke dalam dirinya, mulai dari hal-hal yang berisfat material dan non material seperti memperagakan seekor gajah yang cerdik dengan suasana penonton yang gembira. Oleh sebab itu semakin banyak tanggapan dan gagasan yang dimiliki seseorang, semakin kaya dan luaslah alam internal

\footnotetext{
${ }^{1}$ Nana Syaodih Sukmadinata, Metodologi Penelitian Pendidikan, (Bandung: Remaja Rosdakarya, 2005), hal. 12
} 


\section{muhadasah \\ Jurnal Pendidikan Bahasa Arab \\ INSTITUT AGAMA ISLAM SUNAN KALIJOGO MALANG \\ P-ISSN 2622-6723 E-ISSN 2721-9488 \\ Volume 3, Nomor 1 Juni 2021}

kognitif orang itu. Kemampuan kognitif itu harus dikembangkan melalui belajar. Dengan mengajar menurut kaum konstruktivisme bukanlah kegiatan memindahkan pengetahuan dari pengajar kepada anak didik, melainkan suatu kegiatan yang memungkinkan anak didik membangun sendiri pengetahuannya. Mengajar berarti partisipasi dengan anak didik dalam membentuk pengetahuan, membuat makna, mencari kejelasan, bersikap kritis, dan mengadakan justifikasi. Dengan demikian mengajar adalah suatu bentuk belajar sendiri.

\section{METODE}

Pendekatan yang penulis gunakan dalam penelitian ini adalah penelitian kualitatif deskriptif, yaitu penelitian yang menggunakan latar alamiah dengan maksud menafsirkan fenomena yang terjadi dan melakukan dengan jalan melakukan berbagai metode yang ada. ${ }^{2}$ Selain itu Juga, David William berpendapat bahwa pendekatan kualitatif adalah pengumpulan dan dalam suatu latar alamiah dengan menggunakan metode alamiah dan dilakukan oleh orang atau peneliti yang tertarik secara alamiah. ${ }^{3}$ Dan metode penelitian kualitatif sering disebut metode penelitian naturalistik karena penelitiannya dilakukan pada kondisi yang alamiah (natural setting). Oleh karena itu, teknik pengumpulan data yang digunakan dalam penelitian ini adalah:

a. Observasi

Suatu alat pengumpulan data yang dilakukan dengan mengamati dan mencatat secara sistematik gejala-gejala yang diselidiki. Sedangkan menurut Nasution, observasi adalah dasar semua ilmu pengetahuan. Para ilmuwan hanya dapat bekerja berdasarkan data, yaitu fakta mengenai dunia kenyataan yang diperoleh melalui observasi. ${ }^{4}$

b. Wawancara

Wawancara ini dilakukan oleh dua pihak yaitu pewawancara (interviewer) yang mengajukan pertanyaan dan terwawancara (interviewee) yang memberikan jawaban atas pertanyaan itu. ${ }^{5}$ Wawancara (interview) merupakan alat pengumpulan data atau informasi dengan tanya jawab sepihak yang dikerjakan dengan sistematis dan berlandaskan pada tujuan penelitian. Maka dapat kita simpulkan bahwa wawancara adalah proses tanya jawab dalam

\footnotetext{
2 Moeleong, Lexy J. Metode Penelitian Kualilatif. (Bandung: Remaja Rosdakarya, 2015), hal. 5

3 Moleong. Metodologi Penelitian Kualitatif. (Bandung: Rosdakarya, 2002), hal. 7

4 Nasution. Metode Penelitian Naturalistik Kualitatif. (Bandung: Tarsito, 2007), hal. 56

5 Dedy Mulyana, Metodologi Penelilian Kualitatif. (Bandung: Rosdakarya, 2013), hal. 180
} 


\section{muhadasah \\ Jurnal Pendidikan Bahasa Arab \\ INSTITUT AGAMA ISLAM SUNAN KALIJOGO MALANG \\ P-ISSN 2622-6723 E-ISSN 2721-9488 \\ Volume 3, Nomor 1 Juni 2021}

penelitian dimana dua orang atau lebih bertatap muka mendengarkan secara langsung informasi atau keterangan.

Setelah data terkumpul peneliti akan melakukan analisis data dengan mengelompokkan data-data yang diperoleh yang kemudian dianalisis. Analisis data kualitatif dilakukan dengan jalan bekerja dengan data, mengorganisasikan data, memilah-milihnya menjadi satuan yang dapat dikelola, mensistensikannya, mencari dan menemukan pola, menemukan apa yang penting dan apa yang dipelajari, dan memutuskan apa yang dapat diceritakan kepada orang lain. ${ }^{6}$ Analisis data ini dilakukan untuk menjawab pertanyaan penelitian atau untuk mengkaji hipotesis penelitian yang telah dinyatakan sebelumnya. Data yang telah terkumpul perlu dianalisis dengan cermat dan teliti, sehingga dapat menemukan kesimpulkan yang obyektif dalam penelitian tersebut. Pendekatan yang digunakan dalam penelitian ini bersifat kualitatif dengan tehnik "analisis induktif" ${ }^{7}$

Berdasarkan pengertian di atas dapat disimpulkan bahwa menganalisa data dilakukan dengan cara mengumpulkan data, mengorganisasikan data, memilah-milihnya menjadi satuan yang dapat dikelola data sehingga mudah untuk dibaca. Dengan demikian, maka dalam penelitian peneliti menggunakan analisa data induktif dengan mengolah data yang ada kaitannya dengan penggunaan metode membaca dalam pembelajaran Bahasa Arab.

\section{PEMBAHASAN}

\section{Apa Itu Strategi Belajar Kognitif Bahasa Arab?}

Purpura menyatakan strategi kognitif adalah serangkaian aktivitas sadar atau tidak sadar; perilaku; dan tindakan yang mana secara langsung maupun tidak langsung berkaitan dengan kegiatan memahami, menyimpan, dan mengambil informasi.8 Dari definisi yang disampaikan oleh Purpura ini dapat kita ketahui kognitif memiliki tiga kegiatan yaitu memahami, menyimpan, dan mengambil informasi. Tiga kegiatan ini merupakan urutan. Kegiatan pertama adalah memahami, kegiatan ini biasa dilakukan oleh anak didik terhadap pengetahuan baru. Perilaku memahami pengetahuan baru berperan sebagai penyaringan apakah pengetahuan tersebut layak untuk dipelajari secara lanjut atau tidak. Tidak semua pengetahuan baru bisa

\footnotetext{
${ }^{6}$ Moleong. Metode Penelitian Kualilatif. (Bandung: Remaja Rosdakarya, 2010), hal. 248

7 Bagong Suyanto Sutinah, Metode Penelitian Sosial: Berbagai Alternatif Pendekatan, (Jakarta: Kencana, 2005), hal. 69

${ }^{8}$ Limei Zhang, Metacognitive and Cognitive Strategy Use in Reading Comprehension: A structural equational model approach, (Singapore: Springer, 2018), hlm. 13
} 


\section{muhadasah \\ Jurnal Pendidikan Bahasa Arab \\ INSTITUT AGAMA ISLAM SUNAN KALIJOGO MALANG \\ P-ISSN 2622-6723 E-ISSN 2721-9488 \\ Volume 3, Nomor 1 Juni 2021}

diterima, terkadang anak didik merasa tertarik dan memerlukan pengetahuan tersebut, ada juga yang merasa penasaran saja dengan pengetahuan baru, dan ada yang tidak memerlukan pengetahuan baru. Jadi analisis kebutuhan terhadap pengetahuan baru terjadi pada tahapan memahami.

Kegiatan yang kedua adalah penyimpanan, kegiatan ini sama seperti yang telah dijelaskan pada bab sebelumnya mengenai strategi ingatan. Proses penyimpanan ditujukan untuk menyimpan informasi yang telah dipahami ke dalam ingatan. Pada Bab sebelumnya ditawarkan empat cara untuk mengingat informasi yaitu dengan menciptakan hubungan mental, menggunakan gambar dan suara, melakukan peninjauan (pengulangan) dengan baik, dan menggunakan tindakan fisik untuk merekam informasi melalui gerakan tubuh.

Kegiatan ketiga adalah mengambil informasi. Kegiatan ini belum ada pada strategi ingatan karena kegiatan mengambil informasi ini adalah kegiatan memanggil kembali informasi yang sudah tersimpan. Misalnya jika kita berbicara menggunakan bahasa Arab, maka kita akan mengambil informasi mengenai kosakata bahasa Arab, kaidah gramatikal bahasa Arab, dan cara pengucapan atau penulisan bahasa Arab. Proses pengambilan informasi ini terjadi di dalam ingatan dan berakhir di lisan jika diucapkan atau ditulisan jika dituliskan. Pengambilan informasi ini erat kaitannya dengan pengekspresian ingatan. Pada saat mengekspresikan ingatan, kita memiliki dua cara yaitu apakah informasi dari ingatan tersebut akan disampaikan menggunakan bahasa lisan atau bahasa tulisan. Bahasa lisan memiliki kaidah penyampaiannya yaitu melalui ilmu suara atau fonologi. Dalam bahasa Arab, fonologi memiliki banyak pembahasan, salah satunya adalah tentang makhaarijul huruf yang membahas tentang sifat dan produksi huruf melalui lisan. Sedangkan pada bahasa tulis memiliki kaidah penulisan yang disebut dengan qawaa'idul imla dan khat. Jadi pada proses pengambilan informasi pada anak didik yang belajar bahasa asing akan melakukan tiga pemanggilan informasi yaitu pemanggilan informasi kosakata, pemanggilan informasi kaidah bahasa, dan pemanggilan informasi kaidah penyampaian.

Selain Purpura, Oxford juga menawarkan tiga proses kognitif yaitu pengetahuan deklaratif, pengetahuan asosiatif, dan pengetahuan prosedural. ${ }^{9}$ Pengetahuan deklaratif adalah proses kognitif yang dilakukan secara sadar dan penuh upaya dengan tujuan untuk memperhatikan

\footnotetext{
${ }^{9}$ Rebecca L. Oxford, Teaching and Researching Language Learning Strategies: Self-regulation in context, (New York: Routledge, 2017), hlm. 176
} 


\section{muhadasah \\ Jurnal Pendidikan Bahasa Arab \\ INSTITUT AGAMA ISLAM SUNAN KALIJOGO MALANG \\ P-ISSN 2622-6723 E-ISSN 2721-9488 \\ Volume 3, Nomor 1 Juni 2021}

dan mengatasi informasi baru. ${ }^{10}$ Sedangkan pengetahuan asosiatif adalah proses dimana anak didik mulai mempraktikkan informasi baru yang didapatnya dari pengetahuan deklaratif. ${ }^{11}$ Dan pada pengetahuan prosedural, informasi yang didapat telah didapatkan dan dipraktikkan ini diproses kembali hingga menjadi pengetahuan otomatis yang bisa dilakukan dengan sedikit upaya (tidak mengalami kesulitan) dan bahkan berada pada perilaku tidak sadar. ${ }^{12}$

Sebagai pengantar menuju strategi kognitif, kita sebelumnya telah membahas mengenai pengertian kognitif beserta kegiatan dan proses kognitif yang menawarkan cara-cara praktis untuk melaksanakan strategi kognitif di dalam kelas yaitu berlatih, menerima dan mengirim pesan, menganalisis dan menalar, dan membuat struktur untuk input dan output. ${ }^{13}$

\section{A. Berlatih}

Latihan adalah melakukan pembiasaan terhadap perilaku baru hingga pikiran dan badan merasa familiar terhadap perilaku baru tersebut. Pada beberapa buku ajar tingkat dasar dan menengah biasanya terdapat sesi latihan pada setiap akhir dari Bab. Latihan pada buku ajar ada yang ternilai dan tidak ternilai tetapi memiliki kesamaan yaitu untuk mengetahui sejauh mana pemahaman anak didik terhadap pelajaran yang telah diberikan. Oxford membagi kegiatan berlatih menjadi 5 bagian yaitu pengulangan, praktik formal dengan sistem suara dan tulisan, mengenal dan menggunakan formula serta pola, menggabungkan kembali, dan mempraktikkan secara natural. ${ }^{14}$

\section{Pengulangan}

Pengulangan adalah salah satu cara dalam berlatih. Terdapat dua definisi pengulangan yaitu melakukan hal yang sama beberapa kali dan menirukan apa yang telah diucapkan atau dilakukan oleh orang lain/model yang kadang disebut dengan imitasi. Seorang anak didik selama di dalam kelas telah mempelajari sepuluh kosakata bahasa Arab beserta artinya. Pengulangan jenis kedua yaitu ketika anak didik menonton sebuah video yang memperagakan cara membuat kalimat dalam bahasa Arab. Pertama anak didik akan mengulang sama persis

\footnotetext{
${ }_{10}$ Mu-hsuan Chou, Strategy Use for Reading English for General and Specific Academic Purposes in Testing and Nontesting Context, Reading Research Quarterly, vol. 48, no. 2, 2013

${ }^{11}$ Rebecca L. Oxford, 2017, hlm. 176

12 Chinedu Januarius Osuji, Cognitive and Metacognitive Strategy Use in First and Second Language Reading Comprehension, (United Kingdom: University of Essex, 2017), hlm. 11

${ }^{13}$ Rebecca L. Oxford, 1990, hlm. 44

${ }^{14}$ Rebecca L. Oxford, 1990, hlm. 45
} 


\section{muhadasah \\ Jurnal Pendidikan Bahasa Arab \\ INSTITUT AGAMA ISLAM SUNAN KALIJOGO MALANG \\ P-ISSN 2622-6723 E-ISSN 2721-9488 \\ Volume 3, Nomor 1 Juni 2021}

dengan yang dituliskan di dalam video, yang kedua ia sudah mulai memodifikasi sebagian kata dalam kalimat, dan ketiga ia sudah bisa mengganti semua kata dalam kalimat dengan kaidah gramatikal yang sama dengan tulisan yang diperagakan di dalam video. Proses seperti ini disebut dengan pengulangan imitasi, karena pengulangan dilakukan dengan meniru apa yang telah dilakukan sebelumnya oleh orang lain, bukan diri sendiri.

\section{Praktik formal dengan sistem suara dan tulisan}

Cara yang kedua adalah dengan menggunakan sistem komunikasi yang memiliki dua bentuk yaitu sistem suara dan sistem tulisan. Praktik formal adalah praktik serius yang melibatkan kaidah-kaidah pengucapan dan penulisan. Jika anak didik ingin praktik formal bahasa Arab maka ia harus dengan serius menggunakan kaidah pengucapan dan penulisan yang baku dalam praktiknya. Ketika anak didik berlatih serius untuk menggunakan bahasa Arab, maka ia akan bersinggungan dengan kosakata dan empat unsur bahasa yaitu fonologi (ilmu suara), morfologi (ilmu perubahan kata), sintaksis (ilmu susunan kata), semantik (makna kata), dan pragmatik (konteks kalimat). Untuk latihan yang menggunakan sistem suara, maka yang diperlukan adalah kosakata, morfologi, sintaksis, semantik sebagai materi untuk menyusun ungkapan yang akan disampaikan. Dan pada pengucapannya menggunakan fonologi dan pragmatik, fonologi sebagai kaidah untuk pengucapan yang tepat dari huruf-huruf dan pragmatik adalah kaidah untuk memahami konteks pembicaraan, sehingga ungkapan yang diucapkan tepat sasaran dan tidak menimbulkan permasalahan.

Sedangkan pada sistem tulisan memiliki bahan yang hampir sama dengan sistem suara. Produksi kalimat di dalam ingatan anak didik terdiri dari kosakata, morfologi, sintaksis, dan semantik. Dan pada saat akan diekspresikan menggunakan tulisan, maka anak didik perlu menguasai kaidah penulisan bahasa Arab, seperti qawa'idul imla' dan khat. Di samping itu, pada sistem tulisan juga memerlukan kaidah pragmatik agar tulisan yang dibuat dapat membawa manfaat bagi pembacanya.

Praktik formal ini bukanlah praktik yang dilakukan secara natural. Praktik formal bisa dilakukan di rumah dengan berlatih mengucapkan atau berbicara menggunakan bahasa Arab. Bisa juga dengan berlatih membuat tulisan lepas dengan menggunakan bahasa Arab. Praktik formal biasanya terjadi berulang-ulang dikarenakan banyaknya kesalahan dan kekeliruan ketika menggunakan kaidah bahasa dan kaidah penyampaian. Maka jika menemukan kesalahan dan kekeliruan dalam praktik formal, itu sebenarnya adalah bagian dari latihan 


\section{muhadasah \\ Jurnal Pendidikan Bahasa Arab \\ INSTITUT AGAMA ISLAM SUNAN KALIJOGO MALANG \\ P-ISSN 2622-6723 E-ISSN 2721-9488 \\ Volume 3, Nomor 1 Juni 2021}

tersebut.

3. Mengenal dan menggunakan formula serta pola

Cara ini lebih efektif untuk digunakan pada latihan memperdalam kaidah morfologi dan sintaksis. Unsur bahasa yang menggunakan formula serta pola terdapat pada morfologi dan sintaksis. Misalnya anak didik yang baru belajar mengenal pembuatan kalimat sederhana dlam bahasa Arab dengan pola jumlah fi'liyah yang memiliki formula fi'il + fa'il + maf'ul, maka kalimatnya kتب محمد الدرس.

adalah kata kerja atau fi'il yang memiliki atribut fi'il madhi yang menunjukkan masa lampau, mengandung kata ganti atau dhomir mufrod mudzakkar ghoib yang menunjukkan bahwa fa'il-nya adalah laki-laki tunggal dengan posisi orang ketiga. محمد adalah kata benda atau isim yang menunjukkan nama seseorang, dan menempati formula fa'il pada pola. Kata isim ini memiliki atribut mufrod mudzakkar yang menunjukkan bahwa kata isim ini berjenis laki-laki tunggal. الدرس adalah kata benda atau isim yang menempati formula maf'ul pada pola. memiliki atribut mufrod mudzakkar yang menunjukkan bahwa kata isim ini berjenis laki-laki tunggal.

Pola, formula, dan beserta penjelasannya merupakan proses kognitif untuk mengenal dan menggunakan pola. Proses tersebut terjadi di ingatan anak didik. Anak didik membiasakan diri untuk menggunakan pola tersebut dan bisa saja kosakata yang digunakan berbeda. Tujuannya adalah untuk melekatkan pengetahuan mengenai pola jumlah fi'liyah di ingatan. Anak didik diharapkan sampai familiar dengan pola tersebut, kemudian bisa melanjutkan untuk pola lainnya. Cara ini sudah mengembangkan pengetahuan linguistik, jika sebelumnya hanya mengingat tentang kata dan atributnya, maka pada cara ini sudah berkembang dengan dimasukkannya unsur morfologi dan sintaksis.

\section{Menggabungkan kembali}

Menggabungkan adalah cara untuk mengembangkan pengetahuan-pengetahuan yang terpisah menjadi kelompok atau rangkaian baru untuk menghasilkan pembaharuan yang berarti. Pada konteks belajar bahasa, yang digabungkan adalah elemen-elemen bahasa yang 


\section{muhadasah \\ Jurnal Pendidikan Bahasa Arab \\ INSTITUT AGAMA ISLAM SUNAN KALIJOGO MALANG \\ P-ISSN 2622-6723 E-ISSN 2721-9488 \\ Volume 3, Nomor 1 Juni 2021}

tersimpang di ingatan anak didik. misalnya anak didik yang sudah menguasai pola jumlah ismiyah, jumlah fi'liyah, na'at man'ut, idhafah maka bisa menggabungkan beberapa dari polapola tersebut. kita ambil saja pola jumlah fi'liyah dengan na'at man'ut. Pola jumlah fi'liyah memiliki formula fi'il + fa'il + maf'ul. Sedangkan pola na'at man'ut memiliki pola man'ut + na'at. طالب :Contoh kalimatnya untuk pola jumlah fi'liyah: كتب طالب الدرس dan pola na'at man'ut كتب طالب نشيط Keduanya bisa digabungkan untuk menghasilkan bentuk baru menjadi نشيط. الدرس

Hasil penggabungan ini melahirkan pola baru yaitu fi'il + fa'il bi syakli na'at man'ut + maf'ul. Pembaharuannya adalah pada fa'il yang sudah tidak berupa kata lagi tetapi berupa frasa atau dalam bahasa Arab disebut dengan syibhu al-jumlah. Anak didik yang memiliki penguasaan pola yang banyak bisa dengan bebas mengombinasikan pola-pola tersebut sebagai sarana latihan. Semakin banyak pola yang digunakan maka semakin kompleks proses yang dilalui dan semakin mutakhir juga pola baru yang dihasilkan.

\section{Mempraktikkan secara natural}

Bahasa adalah alat komunikasi yang memerlukan orang lain sebagai penerima pesan yang kita sampaikan. Seorang anak didik yang belajar bahasa selain berlatih sendiri di rumah, juga perlu untuk mempraktikkannya pada kehidupan nyata. Sebelum mempraktikkannya anak didik telah menguasai fonologi, morfologi, sintaksis, semantik, leksikal, dan pragmatik atau penggunaan untuk sosial. ${ }^{15}$ Setelah menguasai unsur bahasa tersebut, maka anak didik dapat menggunakan bahasa yang dikuasainya melalui beberapa aktivitas penggunaan bahasa atau disebut dengan keterampilan berbahasa yang terdiri dari menyimak, berbicara, membaca, dan menulis. ${ }^{16}$

Aktivitas yang pertama adalah menyimak. Menyimak termasuk aktivitas bahasa oral yang pasif karena hanya menerima informasi dari lawan bicara saja. Tetapi melalui aktivitas menyimak anak didik bisa mengasah pendengarannya untuk menganalisis penggunaan fonologi oleh lawan bicara. Pada konteks penggunaan bahasa asing, aktivitas menyimak tidak

\footnotetext{
${ }^{15}$ Julia Herschensohn, language Development and Age, (New York: Cambridge University Press, 2007), hlm. 101 ${ }^{16}$ Muriel Saville-Troike, Introducing Second Language Acquisition, (New York: Cambridge University Press, 2012), hlm. 145
} 


\section{muhadasah \\ Jurnal Pendidikan Bahasa Arab \\ INSTITUT AGAMA ISLAM SUNAN KALIJOGO MALANG \\ P-ISSN 2622-6723 E-ISSN 2721-9488 \\ Volume 3, Nomor 1 Juni 2021}

semudah menyimak bahasa ibu karena pendengar harus menganalisis kata dan kalimat yang diucapkan kemudian diubah kedalam bahasa si pendengar. Disini ingatan akan mengonversi ungkapan bahasa asing menjadi bahasa ibu untuk diketahui maknanya. Pada praktik yang nyata atau natural, salah satu cara terbaik adalah menyimak langsung dari penutur bahasa asing. Untuk melaksanakan ini, akan lebih jika anak didik berada pada wilayah dimana bahasa asing tersebut dipakai, seperti bahasa Arab maka anak didik bisa pergi ke wilayah Sudan. Apabila itu tidak memungkinkan maka anak didik bisa saja menemui beberapa orang yang menggunakan bahasa Arab di wilayah anak didik tersebut. Namun, jika mengakses orangorang tersebut masih terasa sulit, maka anak didik bisa memanfaatkan perkembangan dari produk teknologi sekarang yaitu dengan media sosial seperti Facebook untuk mencari dan memulai interaksi dengan penutur asli bahasa Arab. Lebih mudah lagi jika hanya untuk keperluan menyimak, maka anak didik bisa mencari video berita, percakapan, atau film yang menggunakan bahasa Arab. Sekarang sudah banyak video-video yang berisikan konten pembelajaran untuk bahasa Arab.

Aktivitas yang kedua adalah berbicara, yang tergolong sebagai aktivitas berbahasa oral yang aktif karena orang berbicara merupakan tokoh utama dalam komunikasi sehingga dapat dipastikan akan mengalami aktivitas aktif dan pasif yaitu selain berbicara juga akan menyimak. Aktivitas berbicara adalah lanjutan dari menyimak. Jika menyimak adalah memasukkan informasi kedalam ingatan untuk diproses dan dipahami maknanya maka pada aktivitas berbicara anak didik akan menyusun informasi untuk disampaikan kepada pendengar. Proses penyusunan ini disebut dengan pemanggilan informasi, dimana anak didik akan menetapkan informasi yang akan diungkapkan terlebih dahulu. Kemudian anak didik akan menyeleksi kosakata bahasa pertama yang bisa mewakili informasi yang telah ditetapkan. Selanjutnya anak didik mengubah kosakata bahasa pertama menjadi kosakata bahasa kedua, atau dalam konteks ini adalah bahasa Arab. Setelah kosakata didapatkan, maka anak didik akan menyusunnya menjadi ungkapan yang sesuai dengan kaidah bahasa Arab yang baik dan benar. Dan akhir dari prosesnya adalah ingatan mentransfer informasi yang sudah berbentuk ungkapan bahasa Arab dan menerapkan kaidah fonologi pada lisan sebagai sarana untuk menyampaikan informasi. Anak didik bisa mempraktikkan aktivitas berbicara dengan pengajar bahasa Arab, atau dengan mencari penutur bahasa Arab. Aktivitas berbicara bisa dilakukan secara tatap muka atau bisa juga melalui daring. Dewasa ini, teknologi terus diperbaharui yang berdampak terhadap aktivitas berbicara. Anak didik tidak perlu pergi jauh 


\section{muhadasah \\ Jurnal Pendidikan Bahasa Arab \\ INSTITUT AGAMA ISLAM SUNAN KALIJOGO MALANG \\ P-ISSN 2622-6723 E-ISSN 2721-9488 \\ Volume 3, Nomor 1 Juni 2021}

untuk menemukan penutur bahasa Arab, melalui media sosial anak didik sudah bisa menemukannya dan dapat berbicara layaknya sedang tatap muka meskipun dari jarak jauh. Aktivitas yang ketiga adalah membaca, termasuk aktivitas berbahasa non oral yang pasif. Membaca adalah proses pemerolehan pengetahuan melalui visual. Mata adalah alat utama untuk membaca. Bacaan dilihat oleh mata kemudian dibawa ke ingatan untuk dipahami isi bacaan tersebut. Prosesnya hampir sama dengan aktivitas menyimak, hanya saja berbeda pada alat penerimaan informasinya. Menyimak menggunakan telinga, sedangkan membaca menggunakan mata. Dari keduanya ini sama-sama diproses di dalam ingatan untuk diketahui makna informasi tersbut. Membaca termasuk aktivitas berbahasa non oral yang pasif karena hanya menerima informasi tertulis tanpa memberikan respon. Kemudahan membaca jika dibandingkan dengan menyimak adalah anak didik dapat mengatur ritme masuknya informasi. Maksudnya adalah ketika anak didik membaca buku atau majalah atau koran yang menggunakan bahasa Arab, maka anak didik bisa membacanya dengan perlahan tanpa khawatir akan kehabisan waktu untuk memahaminya. Berbeda dengan mendengarkan yang aktivitasnya lebih spontan dari membaca. Ketika membaca, anak didik juga akan menganalisis unsur-unsur bahasa dari bacaan tersebut agar memudahkan untuk memahaminya. Dalam praktik membaca, apalagi bahasa yang digunakan adalah bahasa asing, maka sudah dipastikan anak didik akan memerlukan waktu untuk memahami. Dalam aktivitas membaca tidak diutamakan banyak bacaan yang dibaca, tetapi seberapa banyak makna yang bisa ditangkap dari bacaan tersebut. Anak didik yang mempraktikkan bahasa melalui membaca akan membutuhkan ketetapan fokus karena membaca adalah aktivitas paling nyaman dan bisa dilakukan dimana saja dan kapan saja tanpa ada faktor yang menghambat.

Aktivitas yang keempat adalah menulis. Menulis termasuk ativitas atau keterampilan berbahasa non oral yang aktif. Sebagai aktivitas yang terakhir dan juga paling tinggi di dalam tatanan keterampilan berbahasa maupun pada kompetensi kognitif. Sama halnya dengan berbicara, menulis adalah salah satu sarana untuk mengekspresikan pemikiran atau pengetahuan atau apa saja yang ada di dalam ingatan. Produktvitas menulis biasanya lebih rumit dan lebih banyak daripada berbicara. Troike menyebutkan langkah-langkah yang bisa dipertimbangkan untuk menjaga kualitas tulisan seperti pengetahuan isi, pengetahuan konteks, dan pengetahuan budaya. ${ }^{17}$ Pengetahuan isi meliputi konsep mental yang akan

${ }^{17}$ Muriel Saville-Troike, hlm. 173 


\section{muhadasah \\ Jurnal Pendidikan Bahasa Arab \\ INSTITUT AGAMA ISLAM SUNAN KALIJOGO MALANG \\ P-ISSN 2622-6723 E-ISSN 2721-9488 \\ Volume 3, Nomor 1 Juni 2021}

dimunculkan, termasuk di dalamnya adalah tema utama, kaidah kebahasaan, dan kaidah penulisan. Pengetahuan konteks memfokuskan pada kesesuaian isi dengan pembaca, atau ketepatan tulisan tengan sasaran pembaca berikut di dalamnya ketepatan tema, ketepatan kaidah kebahasaan, dan ketepatan kaidah penulisan. Dan pengetahuan budaya meliputi pemilihan konten dan konteks yang bisa mengakomodir tujuan penulisan, pembaca, dan lingkungan sekitar. Anak didik yang ingin mempraktikkan aktivitas menulis secara nyata bisa dengan menulis cerita pendek menggunakan bahasa Arab. Menulis cerita adalah bentuk komunikasi satu arah, karena penulis hanya memberikan cerita dan pembaca hanya membaca cerita. Cara lain yang bisa dilakukan anak didik adalah dengan chatting kepada penutur bahasa Arab baik penutur asli maupun tidak. Metode chatting adalah komunikasi dua arah tetapi menggunakan bahasa non oral atau tulis.

Tabel Aktivitas Berbahasa

\begin{tabular}{|l|l|l|}
\hline Tipe dan jenis aktivitas & Oral/lisan & Non oral/tulis \\
\hline Pasif/Reseptif & Menyimak & Membaca \\
\hline Aktif/produktif & Berbicara & Menulis \\
\hline
\end{tabular}

Diadaptasi dari Muriel Saville-Troike. ${ }^{18}$

Tabel diatas adalah rangkuman dari aktivitas berbahasa. Aktivitas yang memproduksi bahasa atau keterampilan aktif adalah berbicara dan menulis. Berbicara menghasilkan ucapan, dan menulis menghasilkan tulisan. Dan aktivitas yang menerima bahasa atau keterampilan pasif adalah menyimak dan membaca. Menyimak menerima bahasa dari ucapan, dan membaca menerima bahasa dari tulisan.

B. Menerima dan mengirim pesan

Strategi menerima dan mengirim pesan adalah proses sirkulasi ide di dalam ingatan. Ide didapatkan melalui aktivitas membaca atau menyimak, disebut juga dengan menerima pesan. Kemudian ide akan disampaikan melalui aktivitas berbicara atau menulis, disebut juga dengan mengirim pesan. Terdapat dua teknik untuk menerima dan mengirim pesan yaitu

${ }^{18}$ Muriel Saville-Troike, hlm. 145 


\section{muhadasah \\ Jurnal Pendidikan Bahasa Arab \\ INSTITUT AGAMA ISLAM SUNAN KALIJOGO MALANG \\ P-ISSN 2622-6723 E-ISSN 2721-9488 \\ Volume 3, Nomor 1 Juni 2021}

mendapatkan ide dengan cepat dan menggunakan fasilitas untuk menerima dan mengirim pesan. ${ }^{19}$

1. Mendapatkan ide dengan cepat

Ide didapatkan dari hasil menyimak atau membaca informasi. Kecepatan seseorang dalam menemukan ide bergantung pada kompetensi ingatannya dan kompetensi penerimaan informasinya. Orang yang sering menyimak, maka akan terbiasa dengan bahasa lisan baik itu bahasa pertama ataupun bahasa asing. Pembiasaan aktivitas ini akan membuat ingatan beradaptasi untuk meningkatkan kecepatan dalam menangkap atau mengumpulkan ide dari informasi. Begitu juga dengan membaca, pembiasaan diri dalam menghadapi bacaan akan membuat ingatan beradaptasi untuk menemukan ide-ide dari bacaan.

2. Menggunakan fasilitas untuk menerima dan mengirim pesan

Ada beberapa fasilitas atau sumber daya yang bisa digunakan untuk meningkatkan aktivitas penerimaan dan pengiriman pesan. Seperti buku sebagai sumber informasi. Sekarang buku sudah ada yang berbentuk elektronik, jadi tidak menghabiskan tempat jika dibawa karena hanya berwujud elektronik atau disebut dengan $e$-book. Untuk menuangkan pesan atau ide juga kita tidak perlu lagi kemana-mana membawa buku dan pena, karena sudah ada aplikasi note pada setiap smartphone yang bisa digunakan untuk menulis dengan instan tanpa menggunakan format yang rumit.

\section{Menganalisis dan menalar}

Menganalisis dan menalar ditujukan untuk menghasilkan informasi baru. Ini adalah strategi paling rumit pada strategi kognitif, karena pada saat menganalisis dan menalar kita akan menggunakan seluruh pengetahuan yang ada pada ingatan. Tidak hanya itu, kemungkinan juga kita akan menambah kembali pengetahuan pada ingatan kita jika pengetahuan yang ada tidak cukup baik atau tidak cukup mampu untuk memunculkan pengetahuan baru. Analisa dan penalaran apabila diterapkan pada anak didik sekolah menengah akan terlihat cukup sulit. Biasanya kegiatan menganalisa dan menalar sering dilakukan oleh mahaanak didik di perpengajaran tinggi. ${ }^{20}$

1. Penalaran deduktif

Deduktif biasa dikenal dengan analisis dari umum ke khusus. Dalam konteks belajar

${ }^{19}$ Rebecca L. Oxford, 1990, hlm. 46

${ }^{20}$ Rebecca L. Oxford, 1990, hlm. 46 


\section{muhadasah \\ Jurnal Pendidikan Bahasa Arab \\ INSTITUT AGAMA ISLAM SUNAN KALIJOGO MALANG \\ P-ISSN 2622-6723 E-ISSN 2721-9488 \\ Volume 3, Nomor 1 Juni 2021}

bahasa Arab, kita bisa menggunakan penelaran deduktif ketika sedang berinteraksi dengan penutur bahasa Arab. Seperti penggunaan kalimat-kalimat doa yang familiar kita gunakan dalam keseharian menjadi bagian dari percakapan lisan maupun tulis.

2. Analisis ekspresi

Menganalisis ekspresi tertulis atau lisan dengan cara memecah ekspresi tersebut menjadi beberapa bagian. Bahasa sederhananya ada menganalisis data tertulis yang didapat dari bacaan atau data tidak tertulis yang didapatkan dari wawancara maupun observasi. Kegiatan ini adalah kegiatan penarikan makna dari sebuah ekspresi. Makna tidak bisa muncul dengan tiba-tiba, melainkan dengan cara memecah ekspresi tersebut menjadi sub-ekspresi.

3. Analisis kontrasif

Analisis kontrasif digunakan untuk mengidentifikasi item-item linguistik yang mengalami perbedaan dalam dua bahasa dan sebagai analisis awal untuk mengetahui kesalahan dan kesulitan ketika belajar bahasa. ${ }^{21}$ Pada analisis ini, memerlukan dua bahasa yang berbeda, perbedaan biasanya dilihat dari sisi fonologi, leksikal, morfologi, sintaksis, dan semantik.

4. Penerjemahan

Penerjemahan adalah ungkapan dalam bahasa lain dari apa yang telah diungkapkan oleh suatu bahasa. ${ }^{22}$ Sebuah informasi yang jika masih menggunakan bahasa pertama maka hanya penutur bahasa pertama saja yang bisa memahaminya. Tetapi jika informasi tersebut diterjemahkan ke bahasa asing yang mendunia, misalnya bahasa Inggris, bahasa Arab, dan bahasa Mandarin maka akan membuka peluang untuk dinikmati oleh pembaca dari Negara yang berbeda. Latihan menerjemahkan bisa dimulai dari level kata, ke kalimat, ke paragraf, hingga satu wacana.

5. Transfer pengetahuan

Transfer pengetahuan adalah menerapkan pengetahuan dari kosakata, konsep, atau struktur dari satu bahasa ke bahasa lain untuk kepentingan pemahaman. Misalnya pengetahuan bahasa Arab, buku yang menjadi sumber belajar kita adalah buku linguistik berbahasa arab. Ketika buku linguistik ini diterjemahkan ke dalam bahasa In donesia, maka sudah menjadi transfer pengetahuan karena memahami bahasa Arab dengan menggunakan

\footnotetext{
${ }^{21}$ M. Kholis Amrullah, Metodologi Penelitian Kualitatif: Pengantar teoritis bagi mahasiswa pendidikan bahasa asing, (Malang: Literasi Nusantara, 2020), hlm. 55

${ }^{22}$ Roger T. Bell, Translation and Translating: Theory and practice, (London: Longman, 1993), hlm. 5
} 


\section{muhadasah \\ Jurnal Pendidikan Bahasa Arab \\ INSTITUT AGAMA ISLAM SUNAN KALIJOGO MALANG \\ P-ISSN 2622-6723 E-ISSN 2721-9488 \\ Volume 3, Nomor 1 Juni 2021}

bahasa Indonesia.

D. Membuat struktur untuk input dan output

Salah satu dari sub-strategi kognitif ini lebih cenderung kepada pengelolaan pengetahuan. Strategi memungkinkan kita untuk memiliki kemandirian dalam memproduksi ungkapan. Strategi ini berkaitan dengan bagaimana cara mengelola input dan menghasilkan output. Oxfort memberikan tiga cara untuk strategi ini yaitu mencatat, meringkas, menyoroti. ${ }^{23}$ 1. Mencatat

Mencatat adalah memberi keterangan lanjut dari sebuah ide yang didapat dari pembicaraan atau bacaan. Jika di dalam buku, kita bisa memberikan catatan pada tepian halaman buku tentang ide yang kita anggap penting. Mencatat juga melatih kita untuk kritis terhadap ide orang lain.

\section{Meringkas}

Meringkas adalah memproduksi makna baru dari sebuah ungkapan, ide, atau wacana dengan menggunakan bahasa kita sendiri dan hasilnya harus lebih ringkas dari sebelumnya. Proses lazim yang biasa terjadi pada kegiatan meringkas adalah membaca atau menerima informasi terlebih dahulu, kemudian memahami informasi tersebut. Informasi yang telah dipahami ini menjadi informasi yang tersimpan dalam ingatan, maka untuk memunculkan ringkasan kita perlu untuk memanggil kembali informasi tersebut dari ingatan.

3. Menyoroti

Menyoroti adalah memberikan tanda pada informasi, biasanya terjadi pada informasi tertulis seperti buku. Menyoroti bisa dengan menggunakan garis bawah, warna, atau penandaan dengan objek lainnya. Fungsi penyorotan ini adalah untuk memberikan tanda bahwa kata atau kalimat tersebut adalah ide pokok atau pokok pikira utama.

\section{KESIMPULAN DAN SARAN}

Sebagai pendidik, sudah merupakan keharusan untuk bertanggung jawab dalam melaksanakan tugasnya, terlebih bagi pendidik atau Dosen Pendidikan Bahasa Arab, karena pendidikan yang diberikannya tidak hanya sekedar mentransferkan pengetahuan secara kognitif pada mahaanak didik melainkan juga bagaimana pendidik tersebut mampu

${ }^{23}$ Rebecca L. Oxford, 1990, hlm. 46 


\section{muhadasah \\ Jurnal Pendidikan Bahasa Arab \\ INSTITUT AGAMA ISLAM SUNAN KALIJOGO MALANG \\ P-ISSN 2622-6723 E-ISSN 2721-9488 \\ Volume 3, Nomor 1 Juni 2021}

menerapkan dan menstimulir sebuah strategi belajar kognitif bahasa Arab kepada mahaanak didik untuk dapat mengaplikasikan pengetahuan yang didapat di dalam tindakan sehari-hari. Oleh karena itu maka setiap pendidik bahasa Arab harus dapat mengerti dan memahami keadaan jiwa setiap anak didik agar melalui pemahaman tersebut, terlebih-lebih dalam masalah strategi belajar kognitif bahasa Arab para pendidik dapat mengukur kemampuan dan tingkat pemahaman mahaanak didik agar setiap pembelajaran yang berlangsung dapat berlangsung secara efektif. Hal ini didukung oleh Mukhtar Martins Yamin yang menyatakan secara umum bahwa "Dosen harus memenuhi ukuran kemampuan yang diperlukan untuk melaksanakan tugasnya, sehingga anak didik dapat mencapai ukuran pendidikan yang tinggi". ${ }^{24}$

${ }^{24}$ Mukhtar Martins Yamin, Metode Pembelajaran yang Berhasil, (Jakarta: Nimas Multimas, 2005), hal. 84 


\section{muhadasah \\ Jurnal Pendidikan Bahasa Arab \\ INSTITUT AGAMA ISLAM SUNAN KALIJOGO MALANG \\ P-ISSN 2622-6723 E-ISSN 2721-9488 \\ Volume 3, Nomor 1 Juni 2021}

\section{DAFTAR PUSTAKA}

Bagong Suyanto Sutinah, Metode Penelitian Sosial: Berbagai Alternatif Pendekatan, (Jakarta: Kencana, 2005)

Chinedu Januarius Osuji, Cognitive and Metacognitive Strategy Use in First and Second Language Reading Comprehension, (United Kingdom: University of Essex, 2017)

Dedy Mulyana, Metodologi Penelilian Kualitatif. (Bandung: Rosdakarya, 2013)

Julia Herschensohn, language Development and Age, (New York: Cambridge University Press, 2007)

Limei Zhang, Metacognitive and Cognitive Strategy Use in Reading Comprehension: A structural equational model approach, (Singapore: Springer, 2018

M. Kholis Amrullah, Metodologi Penelitian Kualitatif: Pengantar teoritis bagi mahaanak didik pendidikan bahasa asing, (Malang: Literasi Nusantara, 2020)

Moeleong, Lexy J. Metode Penelitian Kualilatif. (Bandung: Remaja Rosdakarya, 2015)

Moleong. Metodologi Penelitian Kualitatif. (Bandung: Rosdakarya, 2002)

Moleong. Metode Penelitian Kualilatif. (Bandung: Remaja Rosdakarya, 2010)

Mu-hsuan Chou, Strategy Use for Reading English for General and Specific Academic Purposes in Testing and Nontesting Context, Reading Research Quarterly, vol. 48, no. 2, 2013

Mukhtar Martins Yamin, Metode Pembelajaran yang Berhasil, (Jakarta: Nimas Multimas, 2005)

Muriel Saville-Troike, Introducing Second Language Acquisition, (New York: Cambridge University Press, 2012)

Nana Syaodih Sukmadinata, Metodologi Penelitian Pendidikan, (Bandung: Remaja Rosdakarya, 2005)

Nasution. Metode Penelitian Naturalistik Kualitatif. (Bandung: Tarsito, 2007)

Rebecca L. Oxford, Teaching and Researching Language Learning Strategies: Self-regulation in context, (New York: Routledge, 2017)

Roger T. Bell, Translation and Translating: Theory and practice, (London: Longman, 1993) 